\title{
IRRIGATION WATER QUALITY IN SMOOTH LETTUCE CULTIVATION
}

\author{
Fabrício Thiago Moura Oliveira $^{1 *}$, Lucas Guilherme Moura Oliveira $^{2}$, Thiago Magalhães do Nascimento ${ }^{3}$
}

\author{
SAP 21483 Received: 08/01/2019 Accepted: 11/03/2019 \\ Sci. Agrar. Parana., Marechal Cândido Rondon, v. 18, n. 4, oct./dec., p. 407-411, 2019
}

\begin{abstract}
Qualitative characteristics of surface and groundwater resources have been poorly verified by agricultural producers, who often irrigate their crops with contaminated water. This work aimed to analyze the quality parameters of two water sources (cistern and Brejão Lagoon) used by vegetable producers around the Brejão Lagoon in Sete Lagoas (MG) and to evaluate the influence of water quality on the growth of butterhead lettuce. Physico-chemical and microbiological analyses of the water sources used for irrigation were carried out, in addition to evaluating the height of the plants. The results of the physical-chemical analyses showed that the water studied is contaminated with fecal coliforms, 16.0 NMP (most likely number) in both samples, but at levels acceptable for Conama. For the electrical conductance, the water from the Brejão Lagoon presented a value of $119.7 \mathrm{mg} \mathrm{L}^{-1}$ what is about $6 \mathrm{x}$ greater than that observed in the water from the cistern, which presented a value of $18.89 \mathrm{mg} \mathrm{L}^{-1}$. The quality of the irrigation water did not influence the growth of butterhead lettuce. The $\mathrm{pH}$ of the two irrigation water sources used, fit in the values established by Conama. The vegetables' irrigation sources are contaminated with microorganisms of fecal origin, but that contamination is still within the levels acceptable by Conama. Leafy vegetables can be used as a vehicle of infection for producers and consumers. According to the value determined for the electrical conductivity by Cetesb, the water from the Brejão Lagoon is not within the determined standards.
\end{abstract}

Keywords: Lactuca sativa sp., leafy vegetables, capture sources, physical-chemical analysis.

\section{QUALIDADE DA ÁGUA DE IRRIGAÇÃO NO CULTIVO DE ALFACE LISA}

RESUMO - Características qualitativas dos recursos hídricos superficiais e subterrâneos, têm sido pouco verificadas pelos produtores agrícolas, que frequentemente irrigam suas culturas com água contaminada. O presente trabalho teve por objetivo, analisar os parâmetros de qualidade de duas fontes de água (cisterna e Lagoa do Brejão) utilizadas por produtores de hortaliças do entorno da Lagoa do Brejão, em Sete Lagoas (MG) e avaliar a influência da qualidade da água no crescimento de alface lisa. Foram realizadas análises físico-químicas e microbiológicas das fontes de água utilizadas para irrigação, além de avaliar a altura de plantas. Os resultados das análises físico-químicas mostraram que as águas estudadas, possuem contaminação por coliformes fecais, 16,0 NMP (número mais provável) em ambas amostras, porém, a níveis aceitáveis pelo Conama. Para a condutância elétrica a água proveniente da Lagoa do Brejão, apresentou um valor de $119,7 \mathrm{mg} \mathrm{L}^{-1}$ representando cerca de $6 \mathrm{x}$ maior que aquele observado para a água proveniente da cisterna, que apresentou valor de $18,89 \mathrm{mg} \mathrm{L}^{-1}$. A qualidade da água de irrigação não exerceu influência sobre o crescimento da alface lisa. $\mathrm{O}$ pH das duas águas de irrigação utilizadas, se enquadram nos valores estabelecidos pelo Conama. As fontes de irrigação de hortaliças encontram-se contaminadas com microrganismos de origem fecal, porém ainda estão dentro dos níveis aceitáveis pelo Conama. As hortaliças folhosas podem servir de veículo de infecção para os produtores e consumidores. Conforme o valor determinado para a condutividade elétrica pela Cetesb, a água proveniente da Lagoa do Brejão, não está dentro dos padrões determinados.

Palavras-chave: Lactuca sativa sp., hortaliça folhosa, fontes de captação, análise físico-química.

\section{INTRODUCTION}

Surface and groundwater resources are the main sources of irrigation in Brazilian agriculture, consuming a significant portion of this natural resource. Given the degradation scenario of these resources, physical, chemical and microbiological analyses are essential for monitoring the quality of irrigation water in order to obtain a better response from the crop and therefore increase the gains of the final product in production and quality (PAZ et al., 2000).
The quality of the water used for irrigation is extremely important since it can influence the availability and absorption of nutrients and act directly on the production and quality of the product. In Brazil, studies related to the qualitative characteristics of lake and cistern water used for irrigation in urban centers, mainly by agricultural producers, are of major importance (HERMES et al., 2009).

Falavigna et al. (2005), Fravet (2006), Aquino e Assis (2007) e Hermes et al. (2009) have reported the reality of small vegetable producers located in urban

\footnotetext{
${ }^{1}$ Biólogo, Mestre em educação e docência, Universidade Federal de Minas Gerais (UFMG). E-mail: $\underline{\text { ftmoura1@yahoo.com.br }}$ *Corresponding Author

${ }^{2}$ Mestrando, Programa de Pós-Graduação em Ciência Florestal, Universidade Federal dos Vales do Jequitinhonha e Mucuri (UFVJM). E-mail: lucasguilhermemo@ hotmail.com.

${ }^{3}$ Mestrando, Programa de Pós-Graduação em Engenharia Florestal, Universidade Federal do Paraná (UFPR), Campus Curitiba. E-mail: thiagom.n@outlook.com.
} 
centers, who often irrigate their crops with water containing high levels of contamination. The scarcity of quality water resources directly affects this agronomic sector, which faces a high level of contamination by pathogens that are mainly propagated through hardwoods that are usually consumed fresh.

Due to the fact that they are consumed fresh, vegetables fit into agricultural crops that need to be irrigated with water from appropriate use categories, as stablished in proper legislation. The classes are determined by conditions and standards regarding their main use. Thus, for the irrigation of vegetables, the Conama Resolution 357/2005 (CONAMA, 2005) determines that irrigation water should fall under the classification of fresh water Class I or brackish water Class I for vegetables consumed in their raw state and Class II fresh water for other vegetables.

Quality water affected by physical, chemical or biological attributes influences the dissemination of diseases to consumers and directly interferes with plant development, causing damage to agricultural production (GALBIATTI et al., 2007). The smooth lettuce (Lactuca sativa) cv. belongs to the Asteraceae family and is present in the diet of a considerable amount of the Brazilian population. It has calming properties, is a source of the vitamins $\mathrm{A}, \mathrm{B} 1, \mathrm{~B} 2, \mathrm{~B} 5$ and $\mathrm{C}$, and is a source of minerals such as $\mathrm{Ca}, \mathrm{Fe}, \mathrm{Mg}, \mathrm{P}, \mathrm{K}$ and $\mathrm{Na}$ (RESENDE et al., 2007; HENZ and SUINAGA, 2009).

Considering this scenario, and the need to evaluate the influence of the quality of irrigation water sources on the lettuce growth (GALBIATTI et al., 2007), it is hypothesized that these water sources are not suitable to be used for irrigation. Therefore, this study was designed to evaluate the physical-chemical and microbiological parameters and the development of the plants, using the water from the Brejão Lagoon and the underground source (cistern) used by the producers.

\section{MATERIAL AND METHODS}

The study was carried out at Sete Lagoas Municipal Technical School (ETMSL), under the geographical coordinates: $19^{\circ} 27^{\prime} 28.2^{\prime \prime} \mathrm{S}, 4^{\circ} 12^{\prime} 39.3$ ” W and $758 \mathrm{~m}$ of altitude, from September to December/2016. The climate of the region is $C w a$, according to Köppen climate classification, temperate humid climate with dry winters and hot summers. The collection of the water from the lagoon and the cistern was carried out in the farm 19, under the following geographical coordinates: $19^{\circ} 28^{\prime} 30.41^{\prime \prime} \mathrm{S}$ and $44^{\circ} 12^{\prime} 2.35^{\prime \prime} \mathrm{O}$.

The experiment was set up in half drums in an entirely randomized design, with two treatments containing 15 smooth lettuce seedlings in each half drum, at a $10 \times 12 \mathrm{~cm}$ spacing. The Treatment I was made up of irrigation exclusive from the lake water and in the Treatment II the plants were irrigated exclusively with cistern water. The irrigation was performed manually, where each seedling bed received $1.0 \mathrm{~L}$ of water daily, except on Saturdays and Sundays, where there was no type of irrigation. The water for irrigation was stored in gallons of $5.0 \mathrm{~L}$. A total of $20.0 \mathrm{~L}$ of water from the cistern and 20.0 L of water from the Brejão Lagoon were collected.

The containers (half drums) were made using a plastic drum, cut in half, making two containers of $51.0 \mathrm{~cm} \mathrm{x} 40.0 \mathrm{~cm} \times 19.0 \mathrm{~cm}$ (length, width, height), previously cleaned and identified. Holes were made in the lower part of the containers to allow the draining of irrigation water. Holes were made in the lower part of the containers in order to allow the draining of the irrigation water. Soil collected in the ETMSL was used as substrate. No fertilizers were used. The soil collected was homogenized and placed up to $6.0 \mathrm{~cm}$ from the edge of each half drum.

After 21 days of transplanting the seedlings, their growth in height was evaluated. For that, a graduated ruler was used. The collection and storage of water used for physical-chemical analysis occurred in September 2016, according to NBR 9898/1987. The analyses were performed at the Environmental Analysis Laboratory of the Sete Lagoas Municipal Technical School. The determinations were made in triplicate, according to the methodology suggested by Passari et al. (2011). The following parameters were quantified: color, turbidity, conductivity, $\mathrm{pH}$, total acidity, bicarbonate alkalinity, total hardness, calcium hardness, sulfates, fluorides, total iron, nitrite, ammonia and total dissolved solids $\left(\mathrm{mg} \mathrm{L}^{-1}\right)$. For the evaluation of the presence of total coliforms and fecal coliforms in both water sources, the methodology of multiple tubes was used, as suggested by Funasa (FUNASA, 2013), in which the presumptive phase made it possible to estimate the most likely number (MPN) of microorganisms.

The statistical analyses were made using the $\mathrm{R}$ software version 3.5.0 R Core team (2018). For the analysis of variance, the hypotheses of the autocorrelation in residuals (Durbin-Watson Test), the normality in residuals (Shapiro-Wilk Test) and the homogeneity of variances (Barlett Test) were tested. For the comparisons of the means we used the Tukey test at 5\% significance level. The height data were also distributed in frequency and class intervals. Furthermore, physical-chemical and microbiological analyses of the water sources were performed, which allowed us to verify the degree of water quality of the Brejão lagoon and the cistern's.

\section{RESULTS AND DISCUSSION}

Fecal coliforms constitute a group of microorganisms that are used to indicate a possible contamination of water sources by domestic effluents since they are present in large quantities of human feces. The confirmation of this group of bacteria in a water source may indicate the presence of pathogenic enterobacteria that make it possible to use water for irrigation of leafy vegetables. The physical-mechanical and microbiological results of both irrigation waters (from the cistern and from the Brejão Lagoon) used in this study are presented in Table 1. 
TABLE 1 - Total coliforms (TC), fecal coliforms (FC), physical and chemical characteristics.

\begin{tabular}{lrr}
\hline Parameters analyzed & Water from the cistern & Water from the Brejão Lagoon \\
\hline Color $(\mathrm{HU})$ & 1.00 & 1.00 \\
Turbidity $(\mathrm{FNU})$ & 0.82 & 1.42 \\
Conductivity $\left(\mu \mathrm{S} \mathrm{cm}^{-1}\right)$ & 40.51 & 385.40 \\
$\mathrm{pH}$ & 6.03 & 7.26 \\
Total acidity $\left(\mathrm{mg} \mathrm{L}^{-1}\right)$ & 26.22 & 20.52 \\
Bicarbonate alkalinity $\left(\mathrm{mg} \mathrm{L}^{-1}\right)$ & 12.72 & 90.10 \\
Total hardness $\left(\mathrm{mg} \mathrm{L}^{-1}\right)$ & 12.05 & 68.27 \\
Calcium hardness $\left(\mathrm{mg} \mathrm{L}^{-1}\right)$ & 10.04 & 62.25 \\
Sulfates $\left(\mathrm{mg} \mathrm{L}^{-1}\right)$ & 0.00 & 0.00 \\
Fluorides $\left(\mathrm{mg} \mathrm{L}^{-1}\right)$ & 0.01 & $\mathrm{ND}$ \\
Total iron $\left(\mathrm{mg} \mathrm{L}^{-1}\right)$ & 0.01 & $\mathrm{ND}$ \\
Nitrite $\left(\mathrm{mg} \mathrm{L}{ }^{-1}\right)$ & 0.01 & 0.01 \\
Ammonia $\left(\mathrm{mg} \mathrm{L}^{-1}\right)$ & 0.21 & 1.51 \\
Total dissolved solids $\left(\mathrm{mg} \mathrm{L}^{-1}\right)$ & 18.89 & 119.70 \\
Total coliforms $(\mathrm{MLN})^{*}$ & $>16.00$ & 16.00 \\
Fecal coliforms $(\mathrm{MLN}) *$ & 16.00 & 16.00 \\
\hline
\end{tabular}

HU = hazen units, FNU = formazin nephelometric units, ND = not defined, MLN = most likely number of fecal and total coliforms quantified.

The $\mathrm{pH}$ values in both irrigation sources are in conformity with Conama Resolution 357/2005, which establishes values between 6.0 and 9.0 for water used for the irrigation of vegetables that are consumed raw. However, the high $\mathrm{pH}$ value of the Brejão Lagoon is an indication of the decomposition of organic matter and microbiological activity that results in the release of $\mathrm{CO}_{2}$ (MARTINS et al., 2015).

Based on the physical-chemical and microbiological analysis and Resolution Conama $357 / 2005$, the irrigation of leafy vegetables with water from the Brejão Lagoon is restricted by the categorization of water Class 3 . The irrigation with water from the Brejão Lagoon and from the cistern make the vegetables susceptible to contamination by fecal coliforms, but the values found for coliforms are at acceptable levels. The Conama resolution states the water for irrigation of vegetables must not be contaminated by feces. However, the same resolution allows a certain level of contamination, and the limit is 200 MLN (most likely number) $100 \mathrm{~mL}^{-1}$ of thermotolerant (fecal) coliforms, in water for irrigation of freshly consumed vegetables.

The sanitation control of water sources for later use in the irrigation of vegetables is an important procedure for the farmers, as it is able to ensure the health of workers and consumers mainly when it comes to leafy vegetables, which grow close to the soil. Vegetables such as lettuce have lots of imbricated leaves that promote the retention and survival of micro-organisms and serve as a vehicle for the transmission of diseases to the consumer. Thus, the quality of irrigation water can influence the degree of contamination on vegetables (BONILHA e FALCÃO, 1994).

Both sites presented values of dissolved solids concentration in water in accordance with irrigation use patterns (Table 1), which should be less than $500 \mathrm{mg} \mathrm{L}^{-1}$, according to Conama resolution 357/2005. This parameter is very important when using localized irrigation such as drip and micro-sprinkler irrigation. It is noticeable that high concentrations of solid particles in the water can obstruct the water distribution holes and compromise the irrigation system (SILVA et al., 2011).

The electrical conductivity allows us to infer about the modifications in the composition of water, especially about its mineral concentration. However, this variable does not provide any indication of the values relating to the various components. It is known that as dissolved solids are added to water, the conductivity increases and that high values for the electrical conductivity of water can be an indication of corrosive characteristics. In general, levels above $100 \mu \mathrm{S} \mathrm{cm}^{-1}$ are an indication of corrosive characteristics impacted environments (CETESB, 2005). The results obtained in this study for electrical conductivity show that for the water collected from the cistern, the conductivity found for the water collected in the Brejão Lagoon is above $100 \mu \mathrm{S} \mathrm{cm}^{-1}$. That highlights the impact suffered by receiving significant amounts of waste and dissolved solids. Performing a simple comparison of the data from dissolved solids found in the irrigation sources, it is possible to observe that the water collected in the cistern presents values of $18,89 \mathrm{mg} \mathrm{L}^{-1}$, which is approximately 6 times smaller than those found for water that correspond to $119,7 \mathrm{mg} \mathrm{L}^{-1}$.

For water turbidity, values of 0.82 FNU and 1.42 FNU were found for water collected in the cistern and in the Brejão Lagoon, respectively. Resolution Conama $357 / 2005$ determines that water from Class 1 to $40 \mathrm{FNU}$. Thus, the waters collected in both locations are in conformity with the values determined by Conama.

The results considering the absolute frequency of lettuce plant's height show the highest relative frequency 
in Class 1 , which is equals to $30 \%$, followed by Classes 2 , 4,3 and 5 , with $27 \%, 27 \%, 10 \%$ and $7 \%$, respectively.
Therefore, one can infer a possible normality of data (Table 2).

TABLE 2 - Class and frequency distribution of height data of smooth lettuce plants grown at ETMSL.

\begin{tabular}{lccr}
\hline \multirow{2}{*}{ Classes } & & Frequencies & Relative (\%) \\
\cline { 2 - 4 } & Absolute & Relative & $30 \%$ \\
2 & 9 & 0.30 & $27 \%$ \\
3 & 8 & 0.27 & $10 \%$ \\
4 & 3 & 0.10 & $27 \%$ \\
5 & 8 & 0.27 & $7 \%$ \\
\hline Total & 2 & 0.07 & $100 \%$ \\
\hline
\end{tabular}

The heights were submitted to variance analysis (Table 3). According the analysis of variance table, there are no significant differences between the heights obtained using the two sources of water for irrigation for test $\mathrm{F}$ at $5 \%$ significance level. The coefficient of variation found in the experiment was $10.19 \%$, what demonstrate the good precision of the experiment. The absence of difference between the two treatments tested only, demonstrates the significant importance of a deeper analysis of the physicochemical characteristics used for irrigation purposes. Since the presence of certain substances. This is because the presence if certain substances and pathogens harmful to man may not influence the development of smooth lettuce.

TABLE 3 - Analysis of variance of the height variable of smooth lettuce seedlings.

\begin{tabular}{lcccr}
\hline \multicolumn{5}{c}{ Quadro da análise de variância } \\
\hline FV & GL & SQ & QM & Fc \\
\hline Tratamento & 1 & 1.408 & 14.083 & 0.90849 \\
Resíduo & 28 & 43.405 & 15.502 & $0.34867^{\text {ns }}$ \\
\hline Total & 29 & 44.814 & & \\
\hline CV $(\%)$ & 10.19 & & & \\
\hline
\end{tabular}

In forthcoming studies, analyses of stem diameter parameters, total dry matter and total fresh matter may be included. Furthermore, echophysiological studies such as chlorophyll percentage, fluorescence and photochemical system activity can also be made, since they may provide more concise data on the influence of water quality on vegetable development (GALBIATTI et al., 2007).

\section{CONCLUSIONS}

The quality of the irrigation water had no influence on the growth of smooth lettuce.

The $\mathrm{pH}$ of the irrigation water fit in the values established by Conama.

The sources of irrigation of vegetables are contaminated with microorganisms from fecal origin, but are still within the levels acceptable by Conama.

Vegetables can be an infection vehicle for producers and consumers.

According to the value determined for the electrical conductivity by CETESB, the water from the Brejão Lagoon is not within the determined standards.

\section{ACKNOWLEDGEMENTS}

The authors are grateful to the Municipal Technical School of Sete Lagoas for providing the site for the study and for the financial support.

\section{REFERENCES}

AQUINO, A.M.; ASSIS, R.L. Agricultura orgânica em áreas urbanas e periurbanas com base na agroecologia. Ambiente \& Sociedade, v.10, n.1, p.137-150, 2007.

ABNT. ASSOCIAÇÃO BRASILEIRA DE NORMAS TÉCNICAS. NBR 9898: preservação e técnicas de amostragem de efluentes líquidos e corpos receptores. Rio de Janeiro, RJ: 1987. Disponível em: $<$ http://licenciadorambiental.com.br/wpcontent/uploads/2015/01/NBR-9.898-Coleta-deAmostras.pdf $>$. Acesso em 20 set. 2019.

BONILHA, P.R.M.; FALCÃO, D.P. Ocorrência de enteropatógenos em alfaces e suas águas de irrigação. Alimentação e Nutrição, v.5, n.1, p.87-97, 1994.

CETESB. Qualidade da água. São Paulo, 2005. Disponível

<http//www.CETESB.sp.gov.br/Agua/rios/curiosidades.as p>. Acesso em: 20 set. 2019.

CONAMA. Resolução no 357 de 17 de março de 2005. Classificação dos corpos de água e diretrizes ambientais para o seu enquadramento. Brasília, DF: $2005 . \quad$ Disponível em: <http://www2.mma.gov.br/port/conama/legiabre.cfm?codl egi=459>. Acesso em 20 set. 2019.

FALAVIGNA, L.M.; FREITAS, C.B.R.; MELO, G.C.; NISHI, L.; ARAÚJO, S.M.; GUILHERME, A.L.F. Qualidade de hortaliças comercializadas no noroeste do Paraná, Brasil. Parasitologia Latinoamericana, v.60, n.3-4, p.144-149, 2005. 
FRAVET, A.M.M.F. Qualidade da água utilizada para irrigação de hortaliças na região de Botucatu - SP e saúde pública. 2006. 71p. Dissertação (mestrado) Universidade Estadual Paulista, São Paulo, 2006. Disponível em: <http://hdl.handle.net/11449/93768>. Acesso em: 20 set. 2019.

FUNDAÇÃO NACIONAL DE SAÚDE. Manual prático de análise de água. Brasília: Funasa, 2013, v.4, 150p.

GALBIATTI, J.A.; LUI, J.J.; SABORANO, D.Z.; BUENO, L.F.; SILVA, V.L. Formação de mudas de eucalipto com utilização de lixo orgânico e níveis de irrigação calculados por dois métodos. Engenharia Agrícola, v.27, n.2, p.445-455, 2007.

HENZ, G.P.; SUINAGA, F. Tipos de alface cultivados no Brasil. Brasília: Embrapa Hortaliças, 2009, v.1, 7p.

HERMES, E.; ORSSATTO, F.; BOAS, M.A.V. Análise da qualidade da água e determinação do IQA no rio Piquiri, Ubiratã - Paraná. In: SEMINÁRIO INTERNACIONAL DE CIÊNCIA, TECNOLOGIA E AMBIENTE, 1., 2009, Cascavel, PR. Anais... Cascavel, PR, 2009. 9p.

MARTINS, V.F.C.; MAGALHÃES, B.G.; GOLÇALVES, J.F., MELO, I.G.; SILVA, A.G.; SILVA, M.C.M.D. Avaliação da qualidade da água lagoa José Félix, Sete Lagoas - MG: parâmetros físico-químicos. In: CONGRESSO NACIONAL DE MEIO AMBIENTE DE POÇOS DE CALDAS, 12., 2015, Poços de Caldas, MG. Anais... Poços de Caldas, MG, 2015. 7p.

MAROUELLI, W.A.; MALDONADE, I.R.; BRAGA, M.B.; SILVA, H.R. Qualidade e segurança sanitária da água para fins de irrigação. Brasília, v.1, n.1, 2014, 8p. PASSARI, L.M.Z.G.; SOARES, P.K.; BRUNS, E.B; SCARMINIO, I.S. Estatística aplicada à química: dez dúvidas comuns. Química Nova, v.34, n.5, p.888-892, 2011.

PAZ, V.P.S.; TEODORO, R.E.F.; MENDONÇA, F.C. Recursos hídricos, agricultura irrigada e meio ambiente. Revista Brasileira de Engenharia Agrícola e Ambiental, v.4, n.3, p.465-475, 2000.

R CORE TEAM. R: A language and environment for statistical computing. $\mathrm{R}$ Foundation for Statistical Computing, 2018. Disponível em: <https://www.R-project.org/>. Acesso em: 15 set. 2016. RESENDE, F.V.; SAMINÊZ, T.C.O.; VIDAL, M.C.; SOUZA, R.B.; CLEMENTE, F.M.V. Cultivo de alface em sistema orgânico de produção. Brasília, Embrapa Hortaliças, 2007. 16p.

SILVA, I.N.; FONTES, L.O.; TAVELLA, L.B.; OLIVIEIRA, J.B.; OLIVEIRA, A.C. Qualidade de água na irrigação. Agropecuária Científica no Semi-Árido, v.7, n.3, p.1-5, 2011. 